\title{
KARAKTERISTIK DAN MOTIVASI WISATAWAN DOMESTIK PENGGUNA LOW COST CARRIER PADA MASKAPAI PENERBANGAN LION AIR DI BANDARA INTERNASIONAL NGURAH RAI BALI
}

\author{
Roels Ni Made Sri Puspa Dewi \\ Ni Made Oka Karini \\ Ni Putu Eka Mahadewi \\ Email : roelspuspadewi@gmail.com \\ PS. S1 Industri Perjalanan Wisata \\ Fakultas Pariwisata UNUD
}

\begin{abstract}
Low Cost Carrier has a tight competition, nowadays. There are more product offering to interest tourist which one is cheap ticket price or be familiar call Low Cost Carrier. Which one company in Indonesia applying Low Cost Carrier is Lion Air company. The aims of this study is to determine how the characteristics and motivation domestic tourists used Low Cost Carrier at Lion Air in Ngurah Rai International Airport Bali.

The study was conducted at Lion Air. The object of this research was the characteristics and motivation of tourists who as means of transport choose Low Cost Carrier. Sample of respondents was 105 respondents. The collected data were observation, questionnaire, interview, literature study and documentation. The questionnaires was used as measuring the characteristics and motivation domestic tourists. The research was conducted using descriptive qualitative technique.

The result of this research is domestic tourist characteristic used Lion Air divided into trip descriptor and tourist descriptor. By trip descriptor the tourist has short time to holiday around 3 untill 3 days with purposes of the trip is family trip with period using Lion Air around 2 untill more than 5 times. By tourist descriptor the tourists using Lion Air was teenager or adolescent with average income less than one million. Tourist motivation seen from push factor used Lion Air is cheaper ticket price while pull factor is there are more discount offering by Lion Air. Tourist motivation divided into intrinsic motivation and extrinsic motivation. Intrinsically, domestic tourist motivation used Lion Air by using Maslow theory is Social needs. While extrinsically is nowadays trends used airlines which applying Low Cost Carrier. Recommendation for Lion Air is to improve airlines network to avoid the delay of Lion Airlines.
\end{abstract}

\section{Keywords : Characteristic, Motivation, Tourists, Low Cost Carrier}

\section{Latar Belakang}

Dunia pariwisata tidak bisa lepas dari transportasi, terutama transportasi udara. Moda transportasi yang sangat banyak digunakan wisatawan saat ini adalah maskapai penerbangan. Di Indonesia banyak maskapai besar yang sedang berkembang maupun yang sudah berkembang seperti : Garuda Indonesia, Air Asia Indonesia, Lion Air, Citi Link,
Sriwijaya Air serta maskapai Indonesia lainnya. Maskapai penerbangan tersebut semuanya memiliki kelebihan dan produk masing-masing yang saling bersaing untuk menarik minat wisatawan. Maskapai penerbangan saling bersaing mulai dari persaingan harga dengan penetapan Low Cost Carrier, fasilitas di dalam pesawat yang selalu ditingkatkan dan yang lainnya. 
Salah satu maskapai penerbangan di Indonesia yang menerapkan Low Cost Carrier adalah Maskapai penerbangan Lion Air.

Maskapai penerbangan Lion Air sebagai pioneer maskapai penerbangan layanan Low Cost Carrier mampu menguasai hampir $50 \%$ penerbangan domestik di Indonesia.

Banyak berita di media yang memuat saat ini maskapai penerbangan Lion Air sedang mengalami masalah dalam hal pelayanan penumpangnya terutama dalam hal penanganan keberangkatan penumpang. Sering kali maskapai penerbangan Lion Air mengalami delay sampai 24 jam, Namun dengan mempertahankan kualitas pelayanan dan harga yang murah maka maskapai ini tetap menjadi pilihan utama wisatawan domestik. Tabel jumlah wisatawan domestik pengguna Low Cost Carrier pada Maskapai Penerbangan Lion Air adalah sebagai berikut.

Tabel 1.1

\section{Jumlah Wisatawan Domestik \\ Pengguna \\ Maskapai Penerbangan Lion Air Tahun 2010 - 2015}

\begin{tabular}{|c|c|}
\hline Tahun & $\begin{array}{c}\text { Jumlah } \\
\text { Penumpang } \\
\text { (dalam juta) }\end{array}$ \\
\hline 2010 & 17,79 \\
\hline 2011 & 24,59 \\
\hline 2012 & 23,93 \\
\hline 2013 & 38 \\
\hline 2014 & 40 \\
\hline 2015 & 41,5 \\
\hline
\end{tabular}

Sumber : www.dephub.go.id,2015

Tabel di atas menunjukkan banyaknya wisatawan domestik yang menggunakan maskapai penerbangan Lion Air terus mengalami peningkatan dari tahun ke tahun.

Dari uraian tersebut maka tujuan dari penelitian ini adalah untuk mengetahui karakteristik dan motivasi wisatawan domestik pengguna Low Cost Carrier pada maskapai penerbangan
Lion Air di Bandara Internasional Ngurah Rai Bali.

\section{Metode}

Penelitian ini dilakukan di Bandara Internasional Ngurah Rai Bali. Definisi operasional Variabel dalam penelitan ini ada dua variabel yaitu variabel karakteristik yang terdiri dari dua indikator : trip descriptor dan tourist descriptor dan Motivasi yang terdri dari empat indikator yaitu faktor pendorong, faktor penarik, motivasi intrinsik dan motivasi ekstrinsik.

Teknik pengumpulan data dalam penelitian ini adalah observasi, wwancara, kuesioner, studi kepustakaan dan dokumentasi. Teknik penenetuan sampel dalam penelitian ini menggunakan purposive sampling. Dalam menentukan sampel yang akan dijadikan responden menggunakan teori Hair, et al. (2006) yaitu jumlah indikator observasi dikalikan 5 atau 10. Indikator dari karakteristik wisatawan yang terdiri atas trip descriptor dan tourist descriptor. trip descriptor terdiri dari 9 indikator pertanyaan dan tourist descriptor terdiri atas 8 indikator pertanyaan. Variabel motivasi terdiri dari 4 indikator pertanyaan. Indikator pertanyaan tersebut dikalikan 5 sehingga mendpat 105 responden.

Dalam penelitian ini menggunakan teknik analisis data deskriptif kualitatif. Sehingga mendapat gambaran mengenai karakteristik dan motivasi wisatawan domestik pengguna Low Cost Carrier pada maskapai penerbangan Lion Air di Bandara Internasional Ngurah Rai Bali.

\section{Hasil}

Jumlah wisatawan domestik yang menjadi responden dalam penelitian ini adalah sebesar 105 responden yang merupakan wisatawan domestik yang menggunakan maskapai penerbangan Lion Air yang turun di Bandara Internasional Ngurah Rai Bali. Karakteristik wisatawan domestik dapat dilihat dari dua indikator yaitu Trip 
Descriptor dan Tourist Descriptor. Berikut tabel karakteristik wisatawan pengguna Low Cost Carrier secara Trip Descriptor.

Tabel 3.1

Karakteristik wisatawan pengguna Low Cost Carrier pada maskapai penerbangan Lion Air secara Trip Descriptor

\begin{tabular}{|c|c|c|c|c|}
\hline No. & $\begin{array}{l}\text { Karakteristik } \\
\text { wisataman }\end{array}$ & Hasil penelitian & \begin{tabular}{c|} 
Jumlah \\
xisatawran dari \\
105 responden
\end{tabular} & $\begin{array}{c}\text { Prosentase } \\
\text { karakteristik } \\
(\%)\end{array}$ \\
\hline 1. & Lamanva berlibur & 1-3 hari & 74 & 70 \\
\hline 2. & Jarak perjalanan & Luar pulau & 66 & 63 \\
\hline 3. & $\begin{array}{l}\text { Waktu melakukan } \\
\text { perjalanan }\end{array}$ & Haribiasa & 37 & 35 \\
\hline 4. & $\begin{array}{l}\text { Akomodasi tempat } \\
\text { tinggal }\end{array}$ & $\begin{array}{l}\text { Hotel berbintang } \\
\text { dan numah } \\
\text { saudara atau } \\
\text { keluarga }\end{array}$ & 41 & 39 \\
\hline 5. & Teman Perjalanan & Keluarga & 54 & 51,4 \\
\hline 6. & $\begin{array}{l}\text { Periodisitas } \\
\text { penggunaan } \\
\text { maskapai } \\
\text { penerbangan Lion Air } \\
\end{array}$ & $2-5 \mathrm{kali}$ & 46 & 43,8 \\
\hline 7. & $\begin{array}{l}\text { Tujuan perjalanan } \\
\text { berlibur }\end{array}$ & & 60 & 57,1 \\
\hline 8 & $\begin{array}{l}\text { Pengorganisasian } \\
\text { Pejialanan }\end{array}$ & Diatur sendiri & 84 & 80 \\
\hline 9. & $\begin{array}{l}\text { Rata-Rata Biaya } \\
\text { Perjalanan }\end{array}$ & $>\mathrm{Rp} 1.000 .000$ & 37 & 35,2 \\
\hline
\end{tabular}

Sumber : Hasil penelitian, 2016

Untuk karakteristik wisatawan pengguna pengguna Low Cost Carrier pada maskapai penerbangan Lion Air secara tourist descriptor dapat dilihat pada tabel berikut ini.

Tabel 3.2

Karakteristik wisatawan pengguna

Low Cost Carrier pada maskapai penerbangan Lion Air secara Tourist Descriptor

\begin{tabular}{|l|l|l|c|c|}
\hline No. & \multicolumn{1}{|c|}{$\begin{array}{c}\text { Karakteristik } \\
\text { wisatawan }\end{array}$} & Hasil penelitian & $\begin{array}{c}\text { Jumlah } \\
\text { wisatawan dari } \\
\text { 105 responden }\end{array}$ & $\begin{array}{c}\text { Prosentase } \\
\text { karakteristik } \\
(\%)\end{array}$ \\
\hline 1. & Lamanya berlibur & 1-3 hari & 74 & 70 \\
\hline 2. & Jarak perjalanan & Luar pulau & 66 & 63 \\
\hline 3. & $\begin{array}{l}\text { Waktu melakukan } \\
\text { perjalanan }\end{array}$ & Hari biasa & 37 & 35 \\
\hline 4. & $\begin{array}{l}\text { Akomodasi tempat } \\
\text { tinggal }\end{array}$ & $\begin{array}{l}\text { Hotel berbintang } \\
\text { dan rumah } \\
\text { saudara atau } \\
\text { keluarga }\end{array}$ & 41 & 39 \\
\hline 5. & Teman Perjalanan & Keluarga & 54 & 51,4 \\
\hline 6. & $\begin{array}{l}\text { Periodisitas } \\
\text { penggunaan } \\
\text { maskapai } \\
\text { penerbangan Lion Air }\end{array}$ & 2-5 kali & 46 & 43,8 \\
\hline 7. & $\begin{array}{l}\text { Tujuan perjalanan } \\
\text { berlibur }\end{array}$ & & 60 & 57,1 \\
\hline 8 & $\begin{array}{l}\text { Pengorganisasian } \\
\text { Pejalanan }\end{array}$ & Diatur sendiri & 84 & 80 \\
\hline 9. & $\begin{array}{l}\text { Rata-Rata Biaya } \\
\text { Pejalanan }\end{array}$ & $>$ Rp 1.000.000 & 37 & 35,2 \\
\hline
\end{tabular}

Sumber : Hasil penelitian, 2016

Motivasi wisatawan domestik pengguna Low Cost Air pada maskapai penerbangan Lion Air dipengaruhi oleh faktor pendorong dan penarik serta motivasi intrinsik dan ektrinsik.

Tabel 3.3

Motivasi Wisatawan Domestik

Pengguna Low Cost Carrier Pada Maskapai Penerbangan Lion Air

\begin{tabular}{|l|l|l|c|c|}
\hline No. & $\begin{array}{c}\text { Motivasi } \\
\text { Wisatawan }\end{array}$ & Hasil penelitian & $\begin{array}{c}\text { Jumlah } \\
\text { wisatawan } \\
\text { dari 105 } \\
\text { responden }\end{array}$ & $\begin{array}{c}\text { Prosentase } \\
\text { karakteristik } \\
(\%)\end{array}$ \\
\hline 1. & $\begin{array}{l}\text { Faktor } \\
\text { Pendorong }\end{array}$ & $\begin{array}{l}\text { Harga yang } \\
\text { lebih murah }\end{array}$ & 92 & 87,6 \\
\hline 2. & $\begin{array}{l}\text { Faktor } \\
\text { Penarik }\end{array}$ & $\begin{array}{l}\text { Banyak diskon } \\
\text { yang ditawarkan }\end{array}$ & 44 & 41,9 \\
\hline 3. & $\begin{array}{l}\text { Motivasi } \\
\text { Intrinsik }\end{array}$ & $\begin{array}{l}\text { Kebutuhan } \\
\text { sosial }\end{array}$ & 48 & 45,7 \\
\hline 4. & $\begin{array}{l}\text { Motivasi } \\
\text { Ekstrinsik }\end{array}$ & $\begin{array}{l}\text { Trend pesawat } \\
\text { dengan Low } \\
\text { Cost Carrier }\end{array}$ & 52 & 49,5 \\
\hline
\end{tabular}

Sumber : Hasil penelitian, 2016

\section{Pembahasan}

\subsection{Gambaran umum Maskapai penerbangan Lion Air}

Lion Air didirikan pada Oktober 1999 oleh Rusdi dan Kusnan Kirana bersaudara dan mulai beroperasi pada tanggal 30 juni 2000. Lion Air berada di bawah naungan PT. Lion Mentari Airlines. Maskapai penerbangan Lion Air terus berkembang. Adapun anak perusahaan maskapai penerbangan Lion 
Air yaitu : Wings Air, Lion Bizjet, Batik Air, Malindo dan Thai Lion Air.

Kantor maskapai penerbangan Lion Air cabang Bali didirikin tahun 2003 untuk membantu operasional dari kantor pusat terutama dalam hal penanganan reservasi tiket dan pelayanan penumpang (customer service). Kantor ini sekarang berada di Ibis Styles Hotel by Pass Ngurah Rai Bali.

Maskapai penerbangan Lion Air saat ini bekerjasama dengan 80 agen perjalanan di wilayah Bali untuk mendukung penjualan tiket yang lebih efektif.

Adapun layanan yang dikurangi pada penerapan Low Cost Carrier maskapai penerbangan Lion Air adalah sebagai berikut : tidak adanya layanan makan dan minum, tidak ada lounge (ruang tunggu khusus), pilihan kelas hanya satu, tidak adanya perbedaan antar seat di pesawat dan adanya skema reservasi dini.

Untuk memanjakan konsumennya maskapai penerbangan Lion air memberikan free baggage sebesar 20 $\mathrm{kg}$ dan free airportax sebesar Rp. 75. 000 per orang.

\subsection{Karakteristik Wisatawan \\ Domestik pengguna Low Cost Carrier pada Maskapai Penerbangan Lion Air .}

Karakteristik wisatawan domestik pengguna Low Cost Carrier pada maskapai penerbangan Lion Air dibagi dua yaitu karakteristik wisatawan secara trip descriptor dan secara tourist descriptor

\subsubsection{Karakteristik Wisatawan \\ Domestik pengguna Low Cost \\ Carrier pada Maskapai Penerbangan Lion Air secara Trip Descriptor}

Karakteristik wisatawan secara trip descriptor atau berdasarkan gambaran perjalanan wisatawan domestik adalah lamanya wisatawan domestik berwisata adalah berlibur singkat yaitu hanya 1-3 hari sebanyak 74 orang dari 105 responden. Itu artinya sebanyak $70 \%$ wisatawan domestik berlibur tidak terlalu lama menghabiskan waktu di tempat liburan. Jarak perjalanan atau tujuan berwisata wisatawan domestik adalah ke luar pulau sebanyak 66 responden atau sebesar $63 \%$. Hanya beberapa saja wisatawan domestik yang menggunakan maskapai penerbangan Lion Air untuk ke luar negeri hal ini disebabkan karena rute penerbangan internasional maskapai penerbangan Lion Air hanya terdapat enam rute penerbangan internasional sedangkan rute penerbangan lainnya adalah rute penerbangan domestik.

Waktu melakukan perjalanan wisata dilaksanakan pada hari biasa karena harga tiket pada hari biasa lebih murah di bandingkan pada musim liburan. Akomodasi tempat tinggal wisatawan domestik pengguna maskapai penerbangan Lion Air adalah seimbang antara tinggal di rumah saudara dan menginap di hotel berbintang. Wisatawan domestik yang tinggal di hotel berbintang mempunyai budget liburan yang lebih tinggi.Biasanya wisatawan domestik memilih hotel berbintang karena kenyamanan dan kualitas pelayanannya lebih terjamin. wisatawan domestik yang tinggal rumah saudara atau keluarga kebetulan wisatawan domestik tersebut berlibur memang untuk mengunjungi sanak saudara maupun keluarga di kampung halaman.

Teman perjalanan wisatawan domestik tersebut adalah keluarga. Wisatawan domestik tersebut sudah sering menggunakan maskapai penerbangan Lion Air antara 2 sampai lebih dari 5 kali. Hal ini menunjukkan wisatawan domestik sudah sangat loyal dalam menggunakan maskapai penerbngan Lion Air. Adapun tujuan liburan wisatawan domestik tersebut adalah liburan keluarga dengan pengorganisasian perjalanan di atur sendiri oleh wisatawan. Rata-rata pengeluaran biaya perjalanan wisata wisatawan domestik adalah antara $\mathrm{Rp}$. 800.000 sampai lebih dari Rp. 1.000 .000 sudah termasuk tiket pesawat dan akomodasi . 


\subsubsection{Karakteristik Wisatawan Domestik pengguna Low Cost Carrier pada Maskapai Penerbangan Lion Air secara Trip Descriptor}

Karakteristik wisatawan domestik pengguna Low Cost Carrier pada maskapai penerbangan Lion Air secara tourist descriptor yaitu karakteristik berdasarkan gambaran dari wisatawan yakni lebih banyak penggunanya adalah perempuan dalam menggunakan maskapai penerbangan Lion Air dengan usia rata-rata wisatawan adalah 15-24 tahun. Pendidikan terakhir wisatawan mayoritas SMA dengan berprofesi sebagai pelajar atau mahasiswa yang kebanyakan belum menikah. Jumlah keluarga mereka adalah Beberapa orang, tanpa anak usia di bawah 17 tahun dan belum menikah (masih tinggal bersama orang tua). Karena masih banyak yang berprofesi sebagai mahasiswa maka penghasilan rata-rata dibawah wisatawan domestk tersebut adalah dibawah Rp. 1.000.000, dengan menghandalkan uang saku dari orang tua maupun kerja-kerja freelance.

\subsection{Motivasi Wisatawan Domestik Pengguna Low Cost Carrier Pada Maskapai Penerbangan Lion Air}

Motivasi wisatawan domestik pengguna Low Cost Carrier maskapai penerbangan Lion Air adalah di pengaruhi oleh dua faktor yaitu faktor pendorong dan faktor penarik. Mayoritas faktor pendorong wisatawan domestik menggunakan Low Cost Carrier maskapai penerbangan Lion Air adalah harga tiket yang lebih murah. Harga yang lebih murah tersebut sesuai dengan budget dari wisatawan usia muda yang berwisata menggunakan maskapai penerbangan Lion Air, sehingga karakteristik wisatawan usia muda sangat cocok dengan maskapai penerbangan yang menerapkan Low Cost Carrier

Faktor penarik nya adalah banyak diskon yang ditawarkan. Dapat kita lihat di website maskapai penerbangan Lion Air maupun di situs-situs online yang menawarkan banyak potongan harga oleh maskapai penerbangan Lion Air untuk menarik minat wisatawan domestik dalam melakukan perjalanan wisata menggunakan maskapai penerbangan Lion Air terutama pada musim-musim liburan maupun hari raya besar untuk bisa bersaing dengan maskapai penerbangan lainnya.

Motivasi wisatawan domestik juga dipengaruhi oleh motivasi intrinsik dan motivasi ekstrinsik. Berdasarkan teori Maslow mayoritas motivasi intrinsik wisatawan domestik menggunakan Low Cost Carrier pada maskapai penerbangan Lion Air adalah karena adanya kebutuhan sosial atau berinteraksi dengan orang lain seperti misalnya liburan keluarga untuk mengunjungi saudara maupun keluarga

Motivasi ekstrinsiknya adalah mayoritas wisatawan memilih menggunakan maskapai penerbangan Lion Air karena trend saat ini menggunakan pesawat Low Cost Carrier. Memang saat ini sedang trend menggunakan maskapai penerbangan bertarif rendah atau dikenal dengan Low Cost Carrier.Wisatawan domestik yang ingin berlibur tidak perlu mengeluarkan biaya yang terlalu mahal karena sudah ada pesawat terbang bertarif rendah di Indonesia seperti salah satunya adalah maskapai penerbangan Lion Air.

\section{Simpulan dan Saran \\ 5.1 Simpulan}

Karakteristik wisatawan domestik pengguna Low Cost Carrier pada maskapai penerbangan Lion Air adalah terdiri dari karakeristik berdasarkan trip descriptor adalah lamanya wisatawan domestik berwisata adalah berlibur singkat yaitu hanya 1- 3 hari dengan jarak perjalanan ke luar pulau yang dilaksanakan pada hari biasa. Akomodasi tempat tinggal wisatawan domestik adalah seimbang antara tinggal di rumah saudara dan menginap di hotel berbintang dengan teman perjalanan adalah keluarga. Periodisitas penggunaan maskapai penerbangan Lion Air antara 2 sampai lebih dari 5 
kali. Adapun tujuan liburan wisatawan domestik tersebut adalah liburan keluarga dengan pengorganisasian perjalanan di atur sendiri oleh wisatawan. Rata-rata pengeluaran biaya perjalanan wisata wisatawan domestik adalah antara $\mathrm{Rp} 800.000$ sampai lebih dari Rp 1.000.000.

Karakteristik wisatwan secara tourist descriptor adalah Wisatawan domestik pengguna Low Cost Carrier pada maskapai penerbangan Lion Air adalah lebih banyak perempuan dengan usia rata-rata wisatawan adalah $15-24$ tahun. Pendidikan terakhir wisatawan mayoritas SMA dengan berprofesi sebagai pelajar atau mahasiswa yang kebanyakan belum menikah. Jumlah keluarga mereka adalah Beberapa orang, tanpa anak usia di bawah 17 tahun dan belum menikah (masih tinggal bersama orang tua) dengan penghasilan rata-rata dibawah $\mathrm{Rp} 1.000 .000$.

Motivasi wisatawan domestik pengguna Low Cost Carrier pada maskapai penerbangan Lion Air adalah terdiri atas faktor pendorong yaitu karena tiket pesawat yang murah, faktor penariknya adalah banyak diskon yang ditawarkan. Motivasi intrinsiknya adalah menurut teori Maslow adalah kebutuhan sosial serta motivasi esktrinsiknya adalah trend saat ini menggunakan pesawat Low Cost Carrier.

\subsection{Saran}

1. Maskapai penerbangan Lion Air bisa meningkatkan pangsa pasarnya sehingga bisa mendapatkan wisatawan yang usia produktif dan mempunyai penghasilan yang lebih besar dengan meningkatkan kualitas Sumber Daya Manusia yang dimiliki.

2. Pihak pengelola maskapai penerbangan Lion Air harus melakukan pengecekan pesawat dengan baik agar pesawat tetap dalam kondisi layak terbang walaupun biaya operasional ditekan karena penerapan Low Cost Carrier serta hendaknya memperhatikan jadwal penerbangan agar tidak sering terjadi delay yang menyebabkan keterlambatan keberangkatan pesawat sehingga merusak dan mempengaruhi jadwal penerbangan lainnya .

\section{Daftar Pustaka}

Dinas Perhubungan Republik Indonesia. 2015. Jumlah Penumpang Maskapai Penerbangan Lion Air. www.dephub.go.id,2015. di akses tanggal 4 April 2016.

Hair, et al .2006. Multivariate Data Analyasis. Sixth Edition. New Jersey : Pearson Education.

McIntosh, Robert W., Charles R Goeldner, dan J.R. Brent Ritjie.1995. Tourism : Principle, Practices, Philosophies. (Seventh Edition). New York : John Wiley dan Sons, Inc.

Pitana, I Gde dan Gayatri Putu.2005. Sosiologi Pariwisata. Yogykarta.CV Andi Offset.

Smith, S.L.J. 1989. Tourism Analysis, Harlow : Longan.

Sugiyono. 1999. Statistik untuk Penelitian. Bandung : Alfabeta.

Suwena, I ketut dan Widyatmaja Ngr. 2010. Pengetahuan Dasar Ilmu Pariwisata. Denpasar :Udayana University Press.

Wirayanta, Iman Haryanto. 2014. Studi Kasus Perencanaan Sistem Dan Teknik Transportasi Udara di Indonesia. Yogyakarta: Gadjah Mada University Press.

Vela Royo Marcelo dan Garcia Martinez Esther. 2010. "A Segmentation Analysis And Segments Profile Of Budget Air Travelers". Cuadernos de Turismo, $n$ 26, (2010); Universidad de Murcia. 